\title{
PKM Uji Kompetensi Bidang Keahlian Akuntansi Di SMK Bina Sejahtera Kota Bogor
}

\section{Kompetensi \\ Akuntansi Siswa \\ $S M K$}

\author{
Sudradjat dan Moermahadi Soerja Djanegara \\ Program Studi Akuntansi, Institut Bisnis dan Informatika Kesatuan \\ Bogor, Indonesia
}

E-Mail: sudradajat@ibik.ac.id
Submitted: APRIL 2020

Accepted: MEI 2020

\begin{abstract}
ABSTRAK
Uji Kompetensi Keahlian (UKK) merupakan proses penilaian melalui pengumpulan bukti yang relevan apakah seseorang kompeten atau belum kompeten pada suatu klasifikasi tertentu. UKK diikuti oleh siswa dan siswi Sekolah Menengah Kejuruan (SMK). UKK disusun berdasarkan skema sertifikasi sesuai dengan jenjang kualifikasi peserta UKK yang memuat kemampuan untuk melaksanakan pekerjaan spesifik, operasional dan penjaminan mutu. Peraturan Menteri Pendidikan dan Kebudayaan Nomor 34 tahun 2018 tentang Standar Nasional Pendidikan SMK/MAK, tujuan penilaian hasil belajar adalah: (1) mengetahui tingkat capaian hasil belajar siswa; (2) mengetahui pertumbuhan dan perkembangan peserta didik; (3) mendiagnosis kesulitan belajar peserta didik; (4) mengetahui efektivitas proses pembelajaran; dan (5) mengetahui pencapaian kurikulum. Sedangkan tujuan pelaksanaan Ujian Kompetisi Keahlian (UKK) adalah: (a) mengukur pencapaian kompetensi siswa SMK yang telah menyelesaikan proses pembelajaran sesuai kompetensi keahlian yang ditempuh; (b) memfasilitasi siswa SMK yang akan menyelesaikan pendidikannya untuk mendapatkan sertifikat kompetensi dan/atau sertifikat uji kompetensi; (c) mengoptimalkan pelaksanaan sertifikasi kompetensi yang berorientasi pada capaian kompetensi lulusan SMK sesuai Kerangka Nasional Indonesia; (d) memfasiliasi kerjasama SMK dengan dunia usaha/industri dalam rangka pelaksanaan uji kompetensi sesuai kebutuhan dunia usaha dan dunia industri. Kompetensi keahlian akuntansi adalah salah satu bagian dari bidang keahlian bisnis manajemen di SMK Bina Sejahtera yang mendapat minat dari masyarakat selain bidang keahlian bisnis manajemen yang lain seperti pemasaran dan administrasi perkantoran.
\end{abstract}

Kata Kunci : Kompetensi, SMK, Siswa

\section{PENDAHULUAN}

Analisis Situasi

Berdasarkan Undang-Undang Sistem Pendidikan Nasional No 20 tahun 2003 pasal 15 menyebutkan bahwa pendidikan kejuruan merupakan pendidikan menengah yang mempersiapkan peserta didik untuk bekerja dalam bidang tertentu. Pembelajaran di SMK baik di sekolah maupun dalam dunia kerja bertujuan mengarahkan dan membentuk siswanya agar siap kerja, akan tetapi hal tersebut belum terlaksana dengan baik. Dalam rangka mengukur kompetensi yang telah diperoleh siswa SMK, maka dilaksanakan Ujian Kompetensi Keahlian (UKK).

Uji Kompetensi Keahlian (UKK) merupakan proses penilaian melalui pengumpulan bukti yang relevan apakah seseorang kompeten atau belum kompeten pada suatu klasifikasi tertentu. UKK diikuti oleh siswa dan siswi Sekolah Menengah Kejuruan (SMK). UKK disusun berdasarkan skema sertifikasi sesuai dengan jenjang kualifikasi

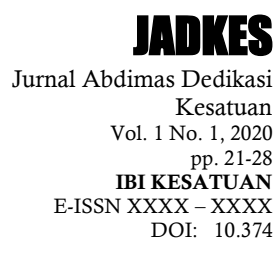


Kompetensi

Akuntansi Siswa

$S M K$

\section{2}

\section{JaDKES}

Jurnal Abdimas Dedikas Kesatuan

Vol. 1 No. 1,2020

pp. $21-28$

IBI KESATUAN

E-ISSN XXXX - XXXX

DOI: peserta UKK yang memuat kemampuan untuk melaksanakan pekerjaan spesifik, operasional dan penjaminan mutu.

Peraturan Menteri Pendidikan dan Kebudayaan Nomor 34 tahun 2018 tentang Standar Nasional Pendidikan SMK/MAK, tujuan penilaian hasil belajar adalah: (1) mengetahui tingkat capaian hasil belajar siswa; (2) mengetahui pertumbuhan dan perkembangan peserta didik; (3) mendiagnosis kesulitan belajar peserta didik; (4) mengetahui efektivitas proses pembelajaran; dan (5) mengetahui pencapaian kurikulum.

Sedangkan tujuan pelaksanaan Ujian Kompetisi Keahlian (UKK) adalah: (a) mengukur pencapaian kompetensi siswa SMK yang telah menyelesaikan proses pembelajaran sesuai kompetensi keahlian yang ditempuh; (b) memfasilitasi siswa SMK yang akan menyelesaikan pendidikannya untuk mendapatkan sertifikat kompetensi dan/atau sertifikat uji kompetensi; (c) mengoptimalkan pelaksanaan sertifikasi kompetensi yang berorientasi pada capaian kompetensi lulusan SMK sesuai Kerangka Nasional Indonesia; (d) memfasiliasi Kerjasama SMK dengan dunia usaha/industri dalam rangka pelaksanaan uji kompetensi sesuai kebutuhan dunia usaha dan dunia industri.

Kompetensi keahlian akuntansi adalah salah satu bagian dari bidang keahlian bisnis manajemen di SMK Bina Sejahtera yang mendapat minat dari masyarakat selain bidang keahlian bisnis manajemen yang lain seperti pemasaran dan administrasi perkantoran.

\section{Tujuan Kegiatan}

Tujuan pelaksanaan uji kompetensi bidang keahlian akuntansi adalah:

1. Untuk mengetahui pencapaian pengetahuan dan keterampilan siswa/siswi SMK Bina Sejahtera Kota Bogor dibidang akuntansi;

2. Mempersiapkan siswa/siswi SMK Bina Sejahtera dalam memasuki dunia kerja sesuai dengan bidang keahlian akuntansi.

\section{Manfaat Kegiatan}

Sasaran uji kompetensi bidang keahlian akuntansi adalah peningkatan pengetahuan dan keahlian siswa/siswi di bidang akuntansi dalam memasuki dunia kerja. Adapun manfaat penyelenggaraan kegiatan uji kompetensi bidang keahlian akuntansi adalah :

1. Sebagai alat evaluasi atas tingkat pengetahuan dan keterampilan siswa/siswi SMK Bina Sejahtera dalam bidang keahlian akuntansi;

2. Sebagai dasar untuk mempersiapkan siswa/siswi SMK Bina Sejahtera di bidang keahlian akuntansi dalam memasuki dunia kerja.

Beberapa pengertian mengenai kompetensi dikemukakan dari berbagai sumber. Keputusan Menteri Tenaga Kerja dan Transmigrasi Republik Indonesia No: Kep. 43/Men/III/ 2008, menjelaskan bahwa kompetensi adalah kemampuan yang dibutuhkan untuk melakukan atau melaksanakan pekerjaan yang dilandasi oleh pengetahuan, keterampilan dan sikap kerja. Sedangkan Mulyasa (2005) merupakan perpaduan dari pengetahuan, keterampilan, nilai dan sikap yang direfleksikan dalam kebiasaan berpikir dan bertindak. Undang-Undang Nomor 13 tahun 2003 tentang ketenagakerjaan menyebutkan bahwa kompetensi kerja adalah kemampuan kerja setiap individu yang mencakup aspek pengetahuan, keterampilan, dan sikap kerja.

Kunandar (2007) menyebutkan bahwa kompetensi dapat dibagi menjadi 5 jenis, yaitu:

1. Kompetensi Intelektual; yaitu perangkat pengetahuan yang dimiliki individu yang dibutuhkan dalam melakukan pekerjaannya.

2. Kompetensi Fisik; yaitu kemampuan fisik individu yang dibutuhkan untuk melaksanakan tugas-tugas dalam pekerjaannya.

3. Kompetensi Pribadi; yaitu perangkat perilaku yang berhubungan dengan kemampuan individu dalam memahami diri, mewujudkan diri, identitas diri, dan transformasi diri.

4. Kompetensi Sosial; yaitu perangkat perilaku tertentu yang menjadi dasar pemahaman diri sebagai bagian dari lingkungan sosial.

5. Kompetensi Spiritual; yaitu kemampuan individu dalam memahami, menghayati, serta mengmalkan kaidah-kaidah keagamaan. 
Statement of the Accounting Principles Board No. 4 menyatakan bahwa akuntansi merupakan aktivitas jasa. Fungsinya menyediakan informasi kuantitatif, khususnya yang bersifat keuangan yang ditujukan atas entitas ekonomik, agar berguna dalam pengambilan keputusan ekonomik. Berdasarkan definisi diatas, terdapat beberapa hal penting berkaitan dengan akuntansi, yakni :

a. Akuntansi menyajikan suatu jasa yang penting dalam lingkungan bisnis saat ini. Mempelajari akuntansi tidak dipandang sebagai sesuatu yang dianggap teoritis semata, namun akuntansi menjadi perangkat yang dipraktikkan.

b. Akuntansi menyajikan khususnya pada informasi keuangan kuantitatif yang digunakan sebagai penghubung atas evaluasi kualitatif dalam pengambilan keputusan.

c. Informasi akuntansi digunakan dalam pengambilan keputusan mengenai bagaimana alokasi sumber daya yang terbatas.

d. Walaupun akuntan menekankan pelaporan atas hal yang telah terjadi, namun informasi tersebut berguna dalam pengambilan keputusan yang akan datang.

Transaksi keuangan yang dilakukan oleh perusahaan hendaknya dicatat dalam sistem akuntansi. Sistem pencatatan akuntansi dapat dilakukan secara manual. Namun dengan perkembangan teknologi informasi dan komunikasi, pencatatan akuntansi dapat dibuat dalam bentuk sistem pencatatan terkomputerisasi. Tahap-tahapan pencatatan transaksi keuangan mulai identifikasi transaksi hingga neraca saldo setelah penutupan disebut dengan istilah siklus akuntansi. Berikut disampaikan siklus akuntansi :

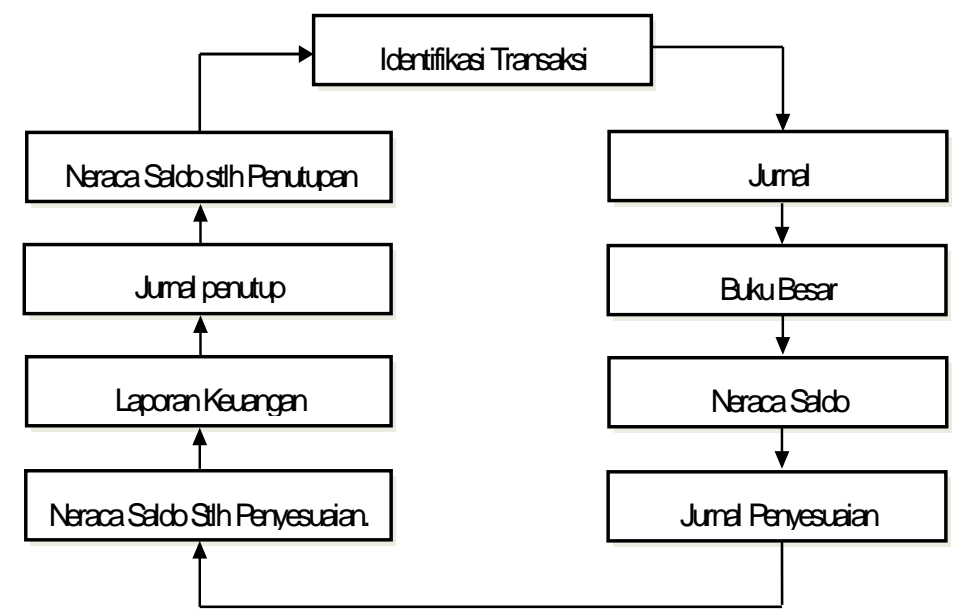

Gambar 1. Siklus Akuntansi

Sumber : Weygandt, Kimmel and Kieso, Financial Accounting Ninth Edition, 2014, Page 179.

Pencatatan akuntansi meliputi beberapa jenis pencatatan,yang terdiri dari :

a. Identifikasi Transaksi

Pada tahap ini entitas melakukan identifikasi manakah jenis kejadian ekonomi yang dapat dicatat dalam proses akuntansi. Hal ini merupakan proses yang sangat penting, dalam menentukan tingkat akurasi pelaporan keuangan.

b. Jurnal (Journal)

Jurnal merupakan pencatatan pertama dalam siklus akuntansi. Pencatatan dalam jurnal menggunakan system tata buku berpasangan (double entry bookiping) yang ditandai dengan system pencatatan transaksi yang dicatat disisi debit dan kredit.

c. Buku Besar (General Ledger)

Buku Besar merupakan kumpulan mutasi transaksi yang terjadi pada masingmasing akun dalam laporan keuangan. Proses pemindahan saldo dalam jurnal ke Buku Besar disebut Posting.
Kompetensi Akuntansi Siswa $S M K$ 
Kompetensi

Akuntansi Siswa $S M K$

\section{4}

\section{JADKES}

Jurnal Abdimas Dedikasi Kesatuan Vol. 1 No. 1,2020 pp. $21-28$ IBI KESATUAN E-ISSN XXXX - XXXX DOI: d. Neraca Saldo (Trial Balance)

Neraca Saldo merupakan kumpulan mutasi saldo akhir seluruh akun dalam buku besar.

e. Jurnal Penyesuaian (Adjustment Entries)

Jurnal penyesuaian merupakan jurnal untuk mencatat akun-akun yang saldonya belum sesuai baik karena belum dibukukan, maupun seharusnya dibebankan.

f. Neraca Saldo Setelah Penyesuaian (Adjustment Trial Balance)

Neraca Saldo Setelah Penyesuaian merupakan kumpulan mutasi saldo akhir seluruh akun dalam buku besar setelah disesuaikan melalu mekanisme jurnal penyesuaian.

g. Laporan Keuangan (Financial Statement)

Laporan Keuangan merupakan hasil / output dari proses akuntansi yang terdiri

dari : Laporan Posisi Keuangan, Laporan Laba Rugi, Laporan Perubahan Laba Ditahan / Modal dan Laporan Arus Kas.

h. Jurnal Penutup (Closing Entries)

Jurnal penutup merupakan jurnal yang dilakukan untuk menutup akun nominal dalam suatu periode.

i. $\quad$ Neraca Saldo Setelah Penutup (Post Closing Trial Balance)

Neraca Saldo Setelah Penutupan merupakan saldo akhir akun buku besar setelah dilakukan penutupan akun nominal.

Laporan Keuangan

Berdasarkan SAK EMKM, laporan entitas mikro, kecil dan minimum terdiri dari :

a. Laporan Posisi Keuangan, merupakan laporan yang menyajikan informasi tentang asset, liabilitas dan ekuitas entitas pada akhir periode laporan.

b. Laporan posisi keuangan meliputi akun-akun sebagai berikut : kas dan setara kas, piutang, persediaan, asset tetap, utang usaha, utang bank dan ekuitas.

c. Laporan laba rugi, merupakan laporan yang menyajikan informasi tentang pendapatan dan beban yang terjadi dalam suatu periode. Laporan laba rugi meliputi akun-akun : pendapatan, beban keuangan dan beban pajak.

Catatan atas laporan keuangan, yang berisi informasi mengenai : (1) suatu pernyataan bahwa laporan keuangan telah disusun sesuai dengan PSAK EMKM; (2) ikhtisar kebijakan akuntansi; (3) informasi tambahan dan rincian akun tertentu yang menjelaskan transaksi penting dan material sehingga bermanfaat bagi pengguna untuk memahami laporan keuangan.

\section{PELAKSANAAN KEGIATAN}

Waktu Pelaksanaan

Kegiatan uji kompetensi bidang keahlian akuntansi diselenggarakan di SMK Bina Sejahtera Kota Bogor. Uji kompetensi dilaksanakan selama 2 hari pada tanggal 4 - 5 Februari 2019.

\section{Kerangka Pemecahan Masalah}

Permasalahan yang diangkat dalam kegiatan pengabdian pada masyarakat adalah meningkatkan pengetahuan dan keterampilan siswa dan siswi SMK Bina Sejahtera Kota Bogor dalam melakukan proses pencatatan akuntansi dan penyusunan laporan keuangan. Kerangka pemecahan masalah dimaksud dilakukan dengan menerapkan langkah kerja dalam pengabdian pada masyarakat sebagai berikut :

1. Jumlah peserta uji kompetensi ditetapkan oleh SMK Bina Sejahtera yakni siswa kelas XII jurusan akuntansi.

2. Uji kompetensi yang dilakukan meliputi materi :

a. Siklus Akuntansi, meliputi :

- Jurnal Umum, Khusus, Penyesuaian dan Penutupan;

- Buku Besar dan Buku Besar Pembantu;

- Neraca Saldo Sebelum dan Setelah Penyesuaian; 
- Kertas Kerja (Worksheet).

b. Penyajian Laporan Keuangan, meliputi :

- Laporan Laba Rugi;

- Laporan Perubahan Modal / Laba Ditahan;

- Laporan Posisi Keuangan;

\section{Khalayak Sasaran Antara Yang Strategis}

Sasaran kegiatan pelatihan adalah siswa dan siswi SMK Bina Sejahtera Kota Bogor kelas XII. Pertimbangan penetapan sasaran ini adalah karena uji kompetensi merupakan rangkaian ujian kelulusan siswa dan siswi kelas XII.

\section{Keterikatan}

Kegiatan pengabdian pada masyarakat ini merupakan kelengkapan proses ujian SMK Bina Sejahtera dimana dalam uji kompetensi harus menghadirkan pendamping yang berasal dari perguruan tinggi dan industri. Teknis pelaksanaan uji kompetensi dikoordinir oleh Lembaga Penelitian dan Pengbdian kepada Masyarakat (LPPM) dengan dukungan sumber daya manusia yang memiliki latar belakang keilmuan dibidang akuntansi. Hal-hal yang berkaitan dengan sumber daya manusia LPPM STIE Kesatuan dapat dijelaskan sebagai berikut :

a. Tenaga Pengajar yang profesional dan berpengalaman.

b. Tenaga Pengajar yang profesional dan berpengalaman dalam pelaksanaan kegiatan pendidikan dan pelatihan.

\section{METODE KEGIATAN}

Metode kegiatan ini berupa pendampingan dalam pelaksanaan uji kompetensi bidang keahlian akuntansi. Berikut disajikan tahapan uji kompetensi yang dilakukan :

1. Tahap Persiapan

Pada tahap persiapan hal yang dilakukan meliputi :

a. Pemaparan rencana uji kompetensi bidang keahlian akuntansi oleh panitia uji kompetensi bidang keahlian SMK Bina Sejahtera;

b. Pembagian bidang keahlian berdasarkan kompetensi penguji eksternal;

c. Penentuan jadwal kegiatan uji kompetensi.

2. Tahap Pelaksanaan Pelatihan

Tahap pelaksanaan merupakan tahapan utama kegiatan uji kompetensi bidang keahlian akuntansi. Pada tahap ini kegiatan uji kompetensi dilakukan sebanyak 3 sessi, yakni :

a. Sessi 1, Siklus Akuntansi bagian pertama, meliputi :

- Jurnal Umum dan Jurnal Khusus,

- Buku Besar dan Buku Besar Pembantu

- Neraca Saldo

b. Sessi 2, Siklus Akuntansi bagian kedua, meliputi :

- Jurnal Penyesuaian

- Neraca Saldo Setelah Penyesuaian

- Kertas Kerja

b. Sessi 3, Penyajian Laporan Keuangan, meliputi :

- Laporan Laba Rugi

- Laporan Perubahan Modal / Laba Ditahan

- Laporan Posisi Keuangan

- Jurnal Penutup

3. Metode Kegiatan

Metode kegiatan uji kompetensi bidang keahlian akuntansi di SMK Bina Sejahtera berupa pendampingan pada waktu pelaksanaan ujian kompetensi berlangsung. Pendamping merupakan komponen pengawas yang berasal dari pihak eksternal SMK Bina Sejahtera Kota Bogor. Tugas pengawas adalah untuk mengawasi jalannya ujian, mengkoreksi jawaban siswa dan memberikan nilai pada lembar jawaban yang tersedia.

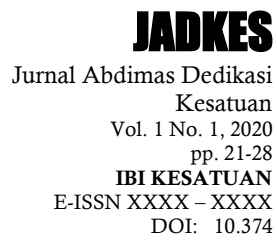


Kompetensi

Akuntansi Siswa

$S M K$

26

\section{JADKES}

Jurnal Abdimas Dedikasi Kesatuan

Vol. 1 No. 1, 2020

pp. $21-28$

IBI KESATUAN

E-ISSN XXXX - XXXX DOI:

\section{HASIL DAN PEMBAHASAN \\ Hasil}

Kegiatan uji kompetensi bidang keahlian akuntansi ditujukan bagi siswa dan siswi SMK Bina Sejahtera Kota Bogor. Waktu penyelenggaraan dilaksanakan pada tanggal 4 - 5 Februari 2019. Kegiatan uji kompetensi bidang keahlian akuntansi di SMK Bina Sejahtera dilakukan berupa pendampingan SMK Bina Sejahtera pada waktu pelaksanaan ujian kompetensi berangsung. Pendamping merupakan komponen pengawas yang berasal dari pihak eksternal SMK Bina Sejahtera Kota Bogor.

\section{Evaluasi Hasil Kegiatan}

Evaluasi uji kompetensi bidang keahlian akuntansi di SMK Bina Sejahtera Kota Bogor berjalan sesuai dengan rencana yang telah ditentukan. Secara umum, siswa dan siswi SMK Bina Sejahtera Kota Bogor dapat melaksanakan uji kompetensi bidang keahlian akuntansi dengan mengerjakan soal kasus yang telah diberikan oleh pihak sekolah. Pemahaman siswa dan siswi SMK Bina Sejahtera Kota Bogor atas bidang akuntansi yang diujikan cukup baik. Hal ini dibuktikan dengan evaluasi atas jawaban peserta yang mayoritas dapat menjawab soal kasus yang diberikan dengan mayoritas jawaban yang benar.

\section{Pembahasan}

Kegiatan program Pengabdian kepada Masyarakat (PkM) yang diselenggarakan oleh Lembaga Penelitian dan Pengabdian pada Masyarakat (LPPM) STIE Kesatuan ini telah terselenggara sesuai dengan rencana yang ditetapkan. Uji kompetensi bidang keahlian akuntansi merupakan rangkaian ujian akhir yang diselenggarakan oleh SMK Bina Sejahtera Kota Bogor bagi siswa dan siswi jurusan akuntansi kelas XII. Dalam pelaksanaannya, SMK Bina Sejahtera Kota Bogor mengikutsertakan pihak eksternal yang berasal dari perguruan tinggi dan industri yang terkait dengan bidang kompetensi di SMK Bina Sejahtera Kota Bogor.

Harapan yang ingin dicapai adalah terbentuknya link and match antara dunia pendidikan yang merupakan lembaga penyuplai tenaga kerja dengan industri sebagai pengguna tenaga kerja. Lembaga pendidikan kejuruan memiliki tanggungjawab untuk membekali pengetahuan dan keterampilan bagi siswa dan siswi yang kelak akan bekerja pada industri sesuai dengan bidangnya. Dengan demikian, angkatan tenaga kerja yang diserap oleh dunia kerja akan optimal sehingga dapat menurunkan tingkat pengangguran di Indonesia.

\section{PENUTUP}

\section{Kesimpulan}

Pelaksanaan kegiatan Pengabdian kepada Masyarakat (PkM) berupa uji kompetensi bidang keahlian akuntansi telah dilaksanakan dengan baik. Indikator kepuasan atas pelatihan tersebut antara lain :

1. Koordinasi yang cukup baik antara SMK Bina Sejahtera dengan STIE Kesatuan dalam penyelenggaraan kegiatan uji kompetensi;

2. Lancarnya kegiatan uji kompetensi bidang akuntansi yang dilakukan oleh SMK Bina Sejahtera Kota Bogor;

3. Siswa dan siswi SMK Bina Sejahtera Kota Bogor secara umum dapat mengerjakan soal yang diberikan dalam uji kompetensi dengan baik, sehingga diharapkan keahlian yang telah dimiliki dapat dipraktikkan dalam dunia kerja yang nyata.

\section{Rekomendasi}

SMK Bina Sejahtera Kota Bogor hendaknya mempertahankan dan meningkatkan jumlah jaringan dengan perguruan tinggi dan dunia industri dalam upaya link and match antara dunia pendidikan dengan industry yang ada diwilayah Kota Bogor. Dengan terjalinnya jaringan tersebut, maka SMK Bina Sejahtera Kota Bogor dapat memahami kebutuhan tenaga kerja dan merumuskan kurikulum yang sesuai dengan kebutuhan 
dunia kerja. Hal ini bertujuan agar lulusan yang dihasilkan dapat diterima dengan baik di dunia kerja.

\section{DAFTAR PUSTAKA}

Adi, S., Martani, D., Pamungkas, B. and Simanjuntak, R.A., 2016. Analysis of the quality of performance report of the local government on websites: Indonesian case. Cogent Business \& Management, 3(1), p.1229393.

Binangkitsari, L., 2018. The Influence of Brand Equity Elements on Purchase Decision and Its Imlication on Customer Loyalty.

Djanegara, M.S., Mulyani, S., Putra, D.M., Zahra, N.A.K. and Mauludina, M.A., 2018. The effect of institutionalization isomorphic pressures and the role of knowledge management on investment decisions of the accounting information systems. Polish Journal of Management Studies, 18.

Fadillah, A., Sujana, S. and Sukartaatmadja, I., 2019. Kajian Minat Studi Lanjut SiswaSiswi SMA dan SMK Kota Bogor Ke Perguruan Tinggi. JAS-PT (Jurnal Analisis Sistem Pendidikan Tinggi Indonesia), 3(1), pp.53-62.

Gendalasari, G.G. and Triandi, T., 2018. Potret Kinerja UMKM Sepatu Di Bogor Dalam Berkompetisi Pada Perekonomian Di Indonesia. Jurnal Ilmiah Manajemen Kesatuan, 6(2), pp.102-108.

Iriyadi, I., 2019. Prevention of Earnings Management through Audit Committee and Audit Quality in the Award-Winning and Non-Winning Companies. Journal of Accounting Research, Organization and Economics, 2(2), pp.155-169.

Kusnandar. 2007. Guru Professional Implementasi Kurikulum Tingkat Satuan Pendidikan (KTSP) Dan Sukses Dalam Sertifikasi Guru. Jakarta: PT Raja Grafindo Persada.

Mulyana, M., Hidayat, L. and Puspitasari, R., 2019. Mengukur Pengetahuan Investasi Para Mahasiswa Untuk Pengembangan Galeri Investasi Perguruan Tinggi. JAS-PT (Jurnal Analisis Sistem Pendidikan Tinggi Indonesia), 3(1), pp.31-52.

Mulyasa. 2005. Menjadi Guru Profesional. Bandung: PT. Remaja Rosda Karya.

Munawar, A., The Effect of Leverage, Dividend Policy, Effectiveness, Efficiency, and Firm Size on Firm Value in Plantation Companies Listed on IDX.

Munawar, A., Syarif, R. and Morita, M., 2019. Persepsi Mahasiswa Atas Galeri Investasi Perguruan Tinggi dan Pengaruhnya Terhadap Minat Berinvestasi. JAS-PT (Jurnal Analisis Sistem Pendidikan Tinggi Indonesia), 3(2), pp.89-96.

Nuraini, A., Gendalasari, G.G. and Sastra, H., 2017. Studi Peningkatan Pertumbuhan dan Nilai Perusahaan Sektor Perkebunan Melalui Analisis Kebijakan Dividend an Profitabilitas. Jurnal Ilmiah Manajemen Kesatuan, 5(2), pp.074-079.

Nurendah, Y. and Rainanto, B.H., 2019, May. The Analysis of Shoes Marketing Mix in Style Successful Benefits SMEs of Shoes Product in Bogor. In 1st International Conference on Economics, Business, Entrepreneurship, and Finance (ICEBEF 2018). Atlantis Press.

Pamungkas, B., Ibtida, R. and Avrian, C., 2018. Factors influencing audit opinion of the Indonesian municipal governments' financial statements. Cogent Business \& Management, 5(1), p.1540256.

Purba, J.H.V. and Munawar, A., 2008. Kajian Dampak Pelatihan terhadap Kinerja Karyawan. Jurnal Ilmiah Ranggagading (JIR), 8(2), pp.95-102.

Peraturan Menteri Pendidikan dan Kebudayaan Nomor 34 tahun 2018 tentang Standar Nasional Pendidikan SMK/MAK.

Setiawan, B. and Panduwangi, M., 2017, August. Measurement of Islamic banking attributes in Indonesia. In Proceedings of the Global Conference on Business and Economics Research (GCBER) (Vol. 1415).

Undang-Undang Nomor 13 tahun 2003 tentang Ketenagakerjaan.
Kompetensi

Akuntansi Siswa

$S M K$

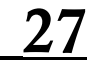


Kompetensi Akuntansi Siswa $S M K$

28
Undang-Undang Sistem Pendidikan Nasional No 20 tahun 2003 tentang Sistem Pendidikan Nasional.

Zuhdi, S., Daud, A., Hanif, R., Nguyen, P.T. and Shankar, K., 2019. Role of Social Media Marketing in the Successful Implementation of Business Management. International Journal of Recent Technology and Engineering, 8.

\section{JADKES}

Jurnal Abdimas Dedikasi Kesatuan 